\title{
EFEKTIVITAS PELAKSANAAN SERTIFIKASI KEANDALAN WEBSITE JUAL BELI ONLINE DALAM MENANGGULANGI PENIPUAN KONSUMEN
}

\author{
${ }^{{ }^{*}}$ Eka Nugraha Putra, ${ }^{{ }^{2}}$ Wika Yudha Shanty dan ${ }^{{ }^{*}}$ Hatarto Pakpahan \\ ${ }^{* 123}$ Fakultas Hukum Universitas Merdeka Malang \\ JI. Terusan Dieng No. 62-64; Malang; 65146; Indonesia; (0341) 580161 \\ eka.nugraha@unmer.ac.id, wika.yudha@unmer.ac.id, hatarto.pakpahan@unmer.ac.id
}

\begin{abstract}
When electronic transactions often consumers are required to enter some personal data in electronic systems. Personal data held by consumers is abused by business actors when consumers enter their personal data first in the online trading website. The sale of personal data to other companies or product offerings that violate the rights of consumers may result from a lack of protection or a security guarantee of personal data from consumers entered on the online buying and selling website. This problem also arises because of the consumer's perspective on the awareness of their inadequate rights and the need for stricter consumer protection law enforcement, particularly in online transactions. This factor causes quite a number of cases related to online consumer fraud, where although it is regulated but the government has not provided a definite form of legal order to provide protection to consumers. This study examines and analyzes the rules regarding certification of reliability in legislation and constraints in its implementation, as well as how the ideal arrangement relates to the implementation of website reliability certification.
\end{abstract}

Keywords: Electronical Transaction, Certificate Authority, Consumer Right.

\begin{abstract}
Abstrak
Saat transaksi elektronik seringkali konsumen diwajibkan memasukkan sejumlah data pribadinya dalam sistem elektronik. Data pribadi yang dimiliki oleh konsumen disalahgunakan oleh pelaku usaha ketika konsumen memasukkan data pribadi mereka pertama kali di dalam website jual beli online tersebut. Penjualan data pribadi kepada perusahaan lain atau penawaran produk yang melanggar hak-hak konsumen dapat terjadi dari minimnya perlindungan atau jaminan keamanan akan data pribadi dari konsumen yang dimasukkan di website jual beli online. Permasalahan ini juga timbul karena perspektif konsumen tentang kesadaran hak mereka yang kurang serta perlunya penegakan hukum perlindungan konsumen yang lebih tegas, khususnya di dalam transaksi online. Faktor tersebut menyebabkan cukup banyak kasus terkait penipuan konsumen online, dimana meskipun sudah diatur tapi pemerintah belum memberikan bentuk pasti pranata hukum untuk memberikan perlindungan terhadap konsumen. Penelitian ini mengkaji dan menganalisis aturan terkait sertifikasi keandalan di dalam peraturan perundang-undangan serta kendala dalam pelaksanaannya, serta bagaimana pengaturan yang ideal terkait dengan pelaksanaan sertifikasi keandalan website.
\end{abstract}

Kata Kunci: Hak Konsumen, Sertifikasi Keandalan, Transaksi Elektronik. 


\section{Pendahuluan}

Salah satu ekses dari perkembangan teknologi informasi adalah kemudahan konsumen dan pelaku usaha dalam bertransaksi. Transaksi yang tadinya bersifat fisik, kini dapat dilakukan secara online, akses terhadap barang dan layanan jasa yang tadinya sulit dijangkau oleh konsumen kini dapat dengan mudah diakses. Transaksi elektronik (E-Commerce) juga memberikan akses dan pelayanan yang cepat bagi konsumen ketika melakukan pembelian barang. Bagi para pelaku usaha pun kehadiran transaksi elektronik juga memberikan kemudahan mengingat mereka dapat dengan mudah melakukan promosi dan penawaran kepada calon konsumen mengenai produk barang atau jasa yang mereka miliki.

Data terakhir menunjukkan bahwa angka kasus penipuan konsumen masih cukup tinggi, dimana pada tahun 2015 tercatat kasus penipuan online meningkat sebesar $66 \%$ (koran-sindo, Januari 2016). Isu perlindungan konsumen dalam kegiatan transaksi elektronik tidak bisa disangkal masih menjadi isu penting untuk dikaji lebih jauh. Dalam hal hak-hak konsumen, terdapat isu akan data pribadi konsumen yang masih minim perlindungan serta isu akan penipuan konsumen dalam kaitan dengan hak-hak dasar konsumen.

Kegiatan transaksi elektronik seringkali konsumen diwajibkan memasukkan sejumlah data pribadi mereka ke dalam sistem elektronik sebelum mereka bisa melakukan kegiatan transaksi, permintaan data pribadi ini memang biasanya dapat digunakan oleh pelaku usaha sebagai data perilaku konsumen dan kepentingan pemasaran produk dari para pelaku usaha. Namun tak jarang pula, data pribadi yang dimiliki oleh konsumen disalahgunakan oleh pelaku usaha ketika konsumen memasukkan data pribadi mereka pertama kali di dalam website jual beli online tersebut. Penjualan data pribadi kepada perusahaan lain atau penawaran produk yang melanggar hak-hak konsumen dapat terjadi dari minimnya perlindungan atau jaminan keamanan akan data pribadi dari konsumen yang dimasukkan di website jual beli online.

Konsumen online juga seringkali harus dihadapkan pada resiko hak-haknya dilanggar dalam bentuk tindak pidana penipuan konsumen. Hakhak dasar konsumen seperti hak memilih, hak atas kenyamanan dan keamanan dan hak didengar sudah diadaptasi dan diatur dalam Pasal 4 UndangUndang Republik Indonesia Nomor 8 Tahun 1999 Tentang Perlindungan Konsumen, namun pada prakteknya dalam transaksi elektronik kerugian konsumen akan produk yang tidak sesuai dengan iklan, cacat produk atau bahkan produk yang tidak dikirimkan masih sering terjadi.

Konsumen akan melakukan kegiatan transaksi elektronik terdapat prinsip kepercayaan (trust) yang harus dijunjung oleh masing-masing baik pelaku usaha maupun konsumen. Prinsip kepercayaan inilah yang kemudian mendorong konsumen untuk melakukan kegiatan transaksi elektronik di sebuah website tertentu, mulai dari memasukkan data pribadi sampai mengirimkan uang untuk pembayaran produk tersebut. Hal tersebut memberikan konsumen kepercayaan dan jaminan keamanan akan transaksi maka dibutuhkan sertifikat keandalan akan website jual beli online yang dituju.

Merujuk Pasal 25 Peraturan Pemerintah Republik Indonesia Nomor 82 Tahun 2012 Tentang Penyelenggaraan Sistem dan Transaksi Elektronik. Sertifikat keandalan adalah dokumen yang menyatakan pelaku usaha yang menyelenggarakan transaksi elektronik telah lulus audit atau uji kesesuaian dari Lembaga Sertifikasi Keandalan. Keberadaan sertifikat keandalan ini idealnya akan memberikan rasa percaya dari calon konsumen dan konsumen tersebut, dikarenakan pencantuman kelayakan website jual beli online yang dikeluarkan oleh Lembaga Sertifikasi Keandalan akan membantu terlaksananya jaminan keamanan bagi konsumen dan keandalan website jual beli online tersebut. 
Pengaturan terkait perlindungan konsumen dalam transaksi elektronik, Undang-Undang Republik Indonesia Nomor 11 Tahun 2008 Tentang Informasi dan Transaksi Elektronik telah mengatur kedua isu yang diuraikan di atas, yakni pada Pasal 26 tentang privasi dan Pasal 28 Ayat 1 tentang penipuan konsumen, namun kedua Pasal tersebut tidak dapat mengakomodir perkembangan terkait penipuan konsumen yang sangat cepat dan dinamis, selain itu kedua Pasal tersebut lebih bersifat penegakan hukum secara represif.

Sementara dengan menggunakan sertifikat keandalan website, tindakan represif dapat dilakukan terhadap tindak pidana penipuan konsumen website jual beli online. Namun pada prakteknya, sertifikasi keandalan website jual beli online belum dijalankan secara masif. Sehingga untuk dapat menangani tindak penipuan konsumen online, diperlukan tindakan preventif yang lebih menjamin hak-hak konsumen, dimana dalam hal ini adalah sertifikasi keandalan website jual beli online. Hingga saat ini, meskipun sudah tercantum dalam regulasi, namun praktek akan sertifikasi keandalan website jual beli online belum benar-benar dipraktekkan dalam rangka mengatur kegiatan transaksi elektronik, khususnya terkait mekanisme perlindungan dan jaminan keamanan dari sertifikasi keandalan website jual beli online tersebut. Bahkan praktek pencantuman trusted seller ini malah banyak dilakukan oleh pihak swasta misalnya www.polisionline.com bukan oleh pemerintah yang notabene regulasinya sudah diatur bahkan sudah mencantumkan adanya Lembaga Sertifikasi Keandalan.

Mengacu pada hal-hal tersebut maka penulis merumuskan judul dalam artikel ini adalah "Implementasi Sertifikasi Keandalan Website Jual Beli Online dalam PP Nomor 82 Tahun 2012 Tentang Penyelenggaraan Sistem dan Transaksi Elektronik untuk Menanggulangi Penipuan Konsumen". Dari latar belakang dan pertanyaan penelitian yang diuraikan di atas, dapat dirumuskan beberapa permasalahan pene- litian yaitu menganalisis dan membuktikan penerapan sertifikasi keandalan website yang dapat melindungi hak-hak konsumen transaksi online serta untuk menemukan dan menerapkan model sertifikasi keandalan website jual beli online berdasarkan Peraturan Pemerintah Republik Indonesia Nomor 82 Tahun 2012 Tentang Penyelenggaraan Sistem dan Transaksi Elektronik yang mampu mereduksi jumlah penipuan konsumen transaksi online.

\section{Pembahasan}

\section{A. Tinjauan Transaksi Elektronik}

Transaksi elektronik, sebagaimana disampaikan Edmon Makarim, sebenarnya tidak ada definisi yang baku tentang istilah dari transaksi elektronik (Makarim, 2003) namun saat ini dengan semakin berkembangnya teknologi beberapa sarjana hukum sudah mulai bisa merumuskan definisi dari transaksi elektronik, Niniek Suparni yang menyatakan bahwa pengertian transaksi elektronik adalah kegiatan bisnis yang menyangkut konsumen, manufaktur, service providers dan pedagang perantara dengan menggunakan jaringan-jaringan komputer, dimana transaksi elektronik sudah meliputi seluruh spektrum kegiatan komersial (Suparni, 2009).

Jelas bahwa aktivitas pertukaran kemudian tidak hanya dalam konteks pertukaran tanpa barang-barang fisik, namun juga barang yang tidak dapat diraba atau dilihat jelas seperti informasi, konteks pertukaran atau transaksi di sini juga merupakan bentuk perdagangan (trading) yang tentunya memerlukan alat pembayaran secara elektronik. Aktivitas transaksi elektronik bisa disimpulkan juga tidak hanya meliputi ketika terjadi transaksi jual beli namun juga keseluruhan tahapan yang terjadi dalam perdagangan dimulai dari pemasaran sampai pengantaran barang.

Pengertian menurut Undang-Undang Republik Indonesia Nomor 11 Tahun 2008 Tentang 
Informasi dan Transaksi Elektronik sebenarnya kurang jelas batasan yang dimaksud perbuatan hukum apakah transaksi jual beli atau pertukaran informasi saja. Mengingat rumusan transaksi elektronik dalam Undang-Undang Republik Indonesia Nomor 11 Tahun 2008 Tentang Informasi dan Transaksi Elektronik di atas kurang jelas maka bisa melihat definisi transaksi elektronik dengan mengacu pada UNCITRAL Model Law for Electronic Commerce yaitu: "Electronic Commerce can be defined as commercial activities conducted through an exchange of information generated, stored or communicated by electronical, optical or analogues means, including EDI, email and so forth."

Definisi ini kemudian dapat dilihat batasannya terdapat pada aktivitas komersial atau perdagangan, yang menggunakan internet sebagai mediumnya senada dengan beberapa definisi dari sarjana-sarjana hukum di atas. Keberadaan internet sebagai medium dalam transaksi elektornik ini kemudian memberikan beberapa ciri khusus, seperti diuraikan oleh Hendra Djaja (2010) yaitu:

1. Transaksi elektronik memudahkan pelaku usaha memasuki pasar global secara cepat tanpa terhalang oleh batas wilayah/geografis;

2. Transaksi elektronik memungkinkan para pihak saling berkomunikasi tanpa harus kenal atau bertemu terlebih dahulu;

3. Keberhasilan transaksi elektronik sangat tergantung kepada keandalan sarana teknologi informasi atau sistem elektronik yang digunakan sehingga faktor keamanan saat berkomunikasi atau bertransaksi menjadi penting.

Sementara menurut Joseph Luhukay seperti dikutip oleh Dikdik M. Arief Mansur dan Elisatris Gultom transaksi elektornik memberikan keuntungan bagi pedagang berupa (Mansur dan Gultom, 2005):

1. Lahan pendapatan yang sulit atau tidak dapat dicapai oleh transaksi konvensional, seperti penjualan langsung produk atau jasa, menjual informasi, banner iklan, dll;
2. Menurunkan biaya operasional, dapat berhubungan langsung dengan pelanggan tanpa harus mempersiapkan ruang yang besar;

3. Memperpendek product cycle dan management supplier;

4. Melebarkan jangkauan terhadap pelanggan di seluruh dunia;

5. Waktu operasi dari transaksi elektronik yang tidak terbatas;

6. Pelayanan pelanggan yang lebih baik karena melalui internet, keluhan dapat disampaikan secara langsung.

Karakteristik dan keuntungan dari penjual dan pembeli dalam transaksi elektronik dapat dilihat dari keberadaan para pihak yang membedakan antara transaksi elektronik dengan transaksi konvensional yaitu (Mansur dan Gultom, 2005):

1. Penjual (merchant, virtual shop) sebagai pihak (perusahaan/perseorangan) yang menawarkan produk, menetapkan harga, terkadang untuk menjadi merchant juga dibutuhkan pendaftaran pada sebuah bank agar memudahkan penjual dalam menerima pembayaran dari konsumen;

2. Pembeli (konsumen) sebagai pihak yang membeli dan mengkonsumsi barang (perusahaan/ perseorangan);

3. Provider sebagai penyelenggara jasa layanan akses internet, dimana internet kemudian menjadi medium utama dalam pelaksanaan transaksi elektronik.

Selain ketiga pihak utama di atas, terdapat beberapa pihak yang juga bisa terlibat dalam transaksi elektronik, yaitu (Mansur dan Gultom, 2005):

1. Acquirer, pihak perantara penagihan dan perantara pembayaran. Perantara penagihan adalah pihak yang meneruskan tagihan kepada penerbit berdasarkan tagihan yang masuk kepadanya yang diberikan oleh penjual barang/ jasa; 
2. Issuer, perusahaan credit card yang menerbitkan kartu, di Indonesia ada beberapa lembaga yang diijinkan untuk menerbitkan kartu kredit seperti Bank, lembaga keuangan non bank, perusahaan non bank serta perusahaan yang membuka cabang dari perusahaan induk di luar negeri;

3. Certificant authorities, pihak ketiga yang netral yang memegang hak untuk mengeluarkan sertifikasi kepada merchant, issuer dan juga card holder.

Perbedaan pelaksanaan pada transaksi elektronik kemudian memerlukan value of trust (nilai kepercayaan) yang lebih dibandingkan transaksi konvensional, terdapat beberapa hal yang harus terpenuhi dalam kaitannya dengan pelaksanaan transaksi elektronik yang terpercaya (Suherman, 2005):

1. Authenticity, Otensitas Identitas dari para pihak;

2. Integrity, Kebenaran Pesan atau konten yang diberikan oleh para pihak;

3. Non-Repudatioan, Pembuktian Kesepakatan dari para pihak (dalam bentuk kontrak atau lainnya);

4. Confidentiality, Kerahasiaan Transaksi, khususnya terkait data pribadi para pihak dan detail transaksi

Salah satu isu hukum dalam pelaksanaan transaksi elektronik saat ini adalah pada poin Integrity, dimana para pelaku usaha jual beli online atau transaksi elektronik ini masih cukup banyak yang memberikan informasi yang tidak lengkap, jelas atau bahkan menipu, khususnya para pelaku usaha yang menggunakan media sosial sebagai wadah layanan jual beli online mereka. Padahal, tingkat kepercayaan konsumen dapat ditumbuhkan dari situ, dimana informasi yang diberikan akan berdampak signifikan pada konsumen, secara positif akan meningkatkan kesetiaan konsumen terhadap pelaku usaha tersebut untuk mengkonsumsi produk atau jasanya (Laila, 2017).

Penyampaian informasi palsu atau penipuan ini sebetulnya sudah diatur di dalam UU ITE, namun bentuk lain berupa distribusi e-mail spam, dimana salah satu unsur dari e-mail spam adalah "commercial" yang bermakna kepentingan komersial dari si pengirim e-mail spam belum mendapat pengaturan yang tegas dan jelas. Hal ini dikarenakan unsur-unsur dalam e-mail spam yang bertujuan merusak yaitu "bulk", "unsolicited" dan "commercial" tidak sepenuhnya diakomodir dalam UU ITE, baik dalam Pasal 32 (Gangguan terhadap data elektronik), maupun Pasal 33 (Gangguan terhadap sistem elektronik), unsur penipuan atau berita bohong dan menyesatkan justru ada Pasal 28 Ayat 1 yang bersifat formil (Putra, 2016).

\section{B. Jenis-Jenis Transaksi Elektronik}

Menurut Adi Sulistya Nugroho, transaksi elektronik merupakan sebuah konsep dasar yang terdiri dari lima aspek, yaitu (Nugroho, 2016):

1. Automation

Otomasi bisnis proses sebagai pengganti proses manual.

2. Streamlining/Integration

Proses yang terintegrasi untuk mencapai hasil yang efisien.

3. Publishing

Kemudahan berkomunikasi dan berpromosi untuk produk dan jasa yang diperdagangkan.

4. Interaction

Pertukaran informasi/data antar pelaku bisnis dengan meminimalisasikan human error.

5. Transaction

Kesepakatan dua pelaku bisnis untuk bertransaksi dengan melibatkan institusi lain sebagai fungsi pembayaran.

Pembahasan atau transaksi elektronik kemudian tidak bisa lepas dari pembahasan kontrak elektronik yang melibatkan pihak-pihak dalam 
transaksi elektronik (kontrak elektronik akan dibahas di bagian berikutnya dari handout ini), mengingat karakteristik yang berbeda dengan transaksi konvensional. Di sini kita dapat melihat dari klasifikasi atas transaksi elektronik yaitu Business to Business"; "Business to Consumer" dan "Consumer to Consumer".

\section{a. Karakter Business to Business}

Business to Business, trading partners atau pihakpihak yang melakukan transaksi biasanya sudah saling kenal, bisa dikarenakan para pihak sudah memiliki ikatan bisnis sebelumnya (kontrak). Terdapat pertukaran data dan informasi yang berkelanjutan dan sifat transaksinya biasanya lebih tertutup. Informasi yang dipertukarkan juga biasanya dilakukan secara berulang dan dengan format data yang telah disepakati bersama, salah satu pihak juga dapat mengirimkan data tanpa harus minta persetujuan lebih dahulu.

\section{b. Karakter Business to Consumer}

Business to Consumer merupakan transaksi dengan servis yang sifatnya sudah umum (sistem yang digunakan juga umum yaitu web), bentuk transaksinya terbuka untuk umum dan informasi tersebar secara umum, sehingga para pihak tidak selalu yang sudah saling kenal atau memiliki ikatan sebelumnya dan seperti perdagangan pada umumnya ada permintaan terhadap barang yang ditransaksikan lalu kemudian dilakukan transaksi. Berbeda dengan Business to Business, jarang sekali informasi menjadi objek dalam transaksi ini, karena kebanyakan transaksi ini melibatkan barang atau jasa sebagai objeknya.

\section{c. Karakter Consumer to Consumer}

Consumer to Consumer yang dilakukan antar konsumen biasanya tidak terlalu rumit, transaksinya dapat dilakukan antar komunitas dan memiliki prinsip-prinsip dasar yang dimiliki pada Business to Consumer.

\section{Tinjauan Sertifikasi Keandalan Website}

Kepercayaan calon konsumen website jual beli online dapat dilihat juga dari salah satu apsek website atau situs informasi yaitu domain, dimana domain yang dimiliki oleh penyedia jasa layanan jual beli online tentu dimiliki oleh pelaku usaha yang bertanggung jawab. Hal ini sesuai dengan prinsip pendaftar pertama domain, dimana prinsip ini menentukan bahwa pemberian nama domain memperhatikan unsur kepercayaan dan itikad baik dari pihak yang mengajukan nama domain tersebut (Djaja, 2014).

Kaitan dengan kepercayaan calon konsumen terhadap website jual beli online, keamanan informasi menjadi salah satu aspek yang sering dipertimbangkan, dimana website dari pelaku usaha dapat memperoleh data pribadi mereka dengan cara Profiling berupa pengisian data secara langsung oleh konsumen untuk mengetahui target marketing mereka dan Cookies yang merupakan data file yang ditulis ke dalam hard disk komputer oleh web server untuk mengidentifikasi user dari website tersebut. Cara-cara pengambilan data ini apabila disalahgunakan dapat memiliki resiko, karena informasi pribadi memiliki tiga karakter yaitu melekat erat dengan kepribadian seseorang, menggambarkan suatu hubungan yang sangat erat dengan orang lain dan merupakan instrumental mapping dari seseorang (Dewi, 2009). Atas dasar tersebut maka jelas dibutuhkan sebuah standar akan keamanan informasi dalam bentuk sertifikasi keandalan.

Sertifikasi keandalan website dibuat untuk menjamin keamanan konsumen berdasarkan kelayakan sebuah website untuk diakses oleh calon konsumen. Berdasarkan Pasal 41 dan Pasal 42 Peraturan Pemerintah Republik Indonesia Nomor 82 Tahun 2012 Tentang Penyelenggaraan Sistem dan Transaksi Elektronik sertifikat keandalan ini merujuk pada standar keamanan informasi yang menekankan pada aspek syarat, prosedur, kebijakan, pengelolaan serta pendidikan dan pelatihan.

Sertifikasi keandalan sendiri prakteknya ditujukan untuk memberikan trust mark bagi para calon konsumen. Dimana sertifikat keandalan ini akan dimiliki oleh pelaku usaha dalam pemenuhan 
persyaratan terkait standar perangkat keras, perangkat lunak, tenaga ahli, keamanan data dan pengelola data (Setiawan, 2014).

Sertifikat keandalan ini biasanya dikeluarkan oleh Certification Authority atau Third Trusted Party yang merupakan badan hukum yang menyediakan layanan keamanan yang dapat dipercaya oleh para pengguna dalam menjalankan pertukaran informasi secara elektronik yang memenuhi 4 aspek keamanan yaitu privacy, authentification, integrity dan non repudiation (Lahaya, Borahima dan Burhamzah, 2014).

\section{Sertifikasi Keandalan Website dan Jaminan Keamanan Informasi dalam Transaksi Online}

Pelaksanaan Transaksi elektronik, terdapat perbedaan dengan transaksi konvensional. Dimana pada transaksi elektronik, jaminan kepercayaan (trust) lebih dibutuhkan agar dapat menjamin keamanan transaksi elektronik serta melindungi hakhak baik dari pelaku usaha, maupun konsumen. Transaksi konvensional kepastian akan hak-hak tersebut diindikasikan dengan kemudahan komunikasi yang dilakukan secara langsung, sehingga pada tahapan negosiasi memudahkan kedua belah pihak, hal ini pun akan membantu terkait jaminan garansi barang atau kondisi barang yang akan ditransaksikan.

Transaksi elektronik jaminan garansi terhadap barang dan keamanan transaksi juga diperlukan mengingat tidak ada pertemuan secara langsung antara pelaku usaha dengan konsumen, sehingga seluruh tahapan transaksi online dilakukan melalui jaringan internet. Keamanan transaksi merupakan salah satu faktor yang menjamin kepercayaan bagi konsumen agar mau melakukan transaksi di sebuah sistem elektronik. Beberapa website transaksi elektronik yang berbasis marketplace ada yang menggunakan Rekber (Rekening Bersama) untuk menjamin keuangan dari konsumen yang disalahgunakan oleh pelaku usaha yang melakukan penipuan, namun sebelum melakukan transaksi, jaminan kepercayaan konsumen terhadap sebuah sistem elektronik yang menjalankan fungsi jual beli dapat diakomodir oleh pelaksanaan sertifikasi keandalan website. Rekber sendiri dapat didefinisikan sebagai sebuah perantara atau pihak ketiga yang membantu keamanan dan kenyamanan transaksi online (Raditio, 2014). Pada sistem ini baik konsumen maupun pelaku usaha akan terhindar dari keraguan.

Berdasarkan Penjelasan Pasal 10 UndangUndang Informasi dan Transaksi Elektronik Sertifikasi Keandalan dimaksudkan sebagai bukti bahwa pelaku usaha yang melakukan perdagangan secara elektronik layak berusaha setelah melalui penilaian dan audit dari badan yang berwenang. Bukti telah dilakukan Sertifikasi Keandalan ditunjukkan dengan adanya logo sertifikasi berupa trust mark pada laman (home page) pelaku usaha tersebut. Badan yang berwenang dalam memberikan penilaian dan audit terhadap pelaku usaha tersebut dinamakan Lembaga Sertifikasi Keandalan, dimana segala hal teknis mengenai Lembaga Sertifikasi Keandalan ini diatur dalam Peraturan Pemerintah Republik Indonesia Nomor 82 Tahun 2012 Tentang Penyelenggaraan Sistem dan Transaksi Elektronik (PP PSTE) dari Pasal 65 sampai dengan Pasal 72.

Secara teknis Pasal 65 Ayat 4 PP PSTE mengatur bahwa Lembaga Sertifikasi Keandalan yang bertugas mengeluarkan Sertifikasi Keandalan sistem elektronik, baik yang beroperasi di Indonesia maupun asing, harus terdaftar di dalam daftar yang dikeluarkan oleh Kementerian Komunikasi dan Informatika. Hal ini berarti, peran Kemkominfo semacam kurator dari data mengenai Lembaga Sertifikasi Keandalan yang dapat dimanfaatkan jasanya oleh para pelaku usaha.

Lembaga Sertifikasi Keandalan berdasarkan PP PSTE membutuhkan beberapa keahlian dan profesi, secara praktek sudah berjalan, salah satunya di Indonesia adalah I-Trust yang dibentuk oleh TELKOM (Kemenkominfo, 2017). Dunia perbankan 
pun, ditambahkan oleh Kemenkominfo, sudah lazim digunakan prinsip trusted mark untuk layanan jasa perbankan yang banyak diaplikasikan pada internet banking. Namun, amanat PP PSTE mengenai pengakuan Lembaga Sertifikasi Keandalan di bawah Kemenkominfo pun hingga saat ini belum dilaksanakan, dengan kata lain belum ada dasar hukum, sehingga belum ada kebijakan atau regulasi secara spesifik dari pemerintah dalam hal ini Kemenkominfo untuk menjalankan praktek Sertifikasi Keandalan di Indonesia. Kendala yang dihadapi oleh Kemenkominfo selain belum disahkannya dasar hukum adalah, kurangnya IT Awareness dari masyarakat, khususnya pengguna jasa transaksi elektronik, sementara cukup banyak kasus phising yang menimbulkan kekhawatiran dari konsumen yang menggunakan jasa transaksi elektronik. Hal ini juga dipengaruhi oleh kepercayaan pelaku usaha yang banyak menggunakan jasa Lembaga Sertifikasi Keandalan Asing yang lebih mudah diaplikasikan, karena mereka menyatukan praktek Sertifikasi Keandalan dan Tanda Tangan Elektronik di dalam satu pranata, yaitu Certificate Authority (CA) (Kemenkominfo, 2017).

Rancangan teknis terkait pelaksanaan Sertifikasi Keandalan, Kemenkominfo akan mewajibkan seluruh Lembaga Sertifikasi Keandalan (LSK) yang ada untuk mendaftar, termasuk LSK Asing, karena banyak penyelenggara jasa elektronik yang menggunakan jasa LSK Asing ini, yang mana situasi tersebut juga kembali pada keberadaan prinsip trust dari para penyelenggara sistem elektronik kepada LSK Asing ini yang dipengaruhi oleh operasional mereka yang lebih dulu berjalan dari pada LSK asal Indonesia, sementara LSK Indonesia walaupun sudah ada baru digunakan secara internal di perusahaan masing-masing (Kemenkominfo, 2017).

Implikasi secara khusus nantinya apabila tidak semua LSK terdaftar di Indonesia, akan memberikan kemudahan, khsusunya bagi konsumen untuk mengetahui mana LSK yang terjamin keamanannya dalam melakukan transaksi, sehingga ketika ada permasalahan antara konsumen dengan penyelenggara sistem elektronik yang menggunakan jasa LSK yang terdaftar, Kemenkominfo dapat melakukan tindakan teguran atau tindak lanjut lainnya (Kemenkominfo, 2017).

\section{E. Model Penerapan Sertifikasi Keandalan Website untuk Menjamin Hak-Hak Kon- sumen di Indonesia}

Sebagaimana disebutkan sebelumnya, dibeberapa negara praktek Sertifikasi Keandalan digabungkan dengan pelaksanaan tanda tangan digital dalam satu pranata dan lembaga. Terdapat beberapa isu yang masuk dalam aspek berjalannya infrastruktur terkait sertifikasi keandalan dan tanda tangan digital, seperti otentifikasi, integritas dan tidak adanya penolakan dari pemangku kebijakan terkait. Terdapat beberapa pendekatan terkait isu pembuatan aturan sertifikat keandalan dan tanda tangan digital, pendekatan ini dapat digunakan untuk menguji secara spesifik pada pertanggungjawaban otoritas yang memberikan sertifikasi tersebut.

Pendekatan pertama, Minimalist Approach, adalah pendekatan minimal yang memiliki tujuan utama untuk memfasilitasi pelaksanaan sertifikasi keandalan dan tanda tangan digital secara umum. Pendekatan ini biasanya tidak membawa protokol spesifik atau teknologi tertentu. Kerangka hukum yang disusun akan mencari permasalahan hukum yang sudah ada untuk mengenali dan menegakkan sertifikasi keandalan dan tanda tangan digital tersebut.

Pendekatan kedua, Prescriptive Approach, lebih merupakan pendekatan yang bersifat menentukan, dimana biasanya melibatkan inisiatif untuk menegakkan kerangka hukum dalam infrastruktur terkait. Peraturan hukum di dalam pendekatan ini akan bertujuan untuk menciptakan pranata baru sertifikat keandalan dan tanda tangan digital ter- 
sebut dan cenderung memaksakan operasional tertentu dan kebutuhan finansial akan penegakkannya.

Pendekatan ketiga, Hybrid Approach, merupakan gabungan dari dua pendekatan sebelumnya. Praktek dari pendekatan ini adalah adanya ruang lingkup pembuatan kerangka hukum yang ditentukan standarnya sebagai bagian dari prediksi atas permasalahan hukum yang mungkin muncul dengan mengintegrasikan pilihan otentifikasi teknologi terhadap implementasi sertifikasi keandalan dan tanda tangan digital tersebut.

Berdasarkan hasil penelusuran peneliti, konteks bidang e-commerce Indonesia cenderung menggunakan pendekatan Minimal Approach yang memfasilitasi pelaksanaan sertifikasi keandalan secara umum, hal ini diindikasikan dengan keberadaan PP PSTE yang telah mengatur baik sertifikasi keandalan website, namun sifatnya baru secara umum, belum ada peraturan yang lebih teknis dalam bentuk Peraturan Menteri Kominfo. Sementara Prescriptive Approach juga tidak terlaksana di Indonesia, mengingat praktek penerapan sertifikasi keandalan website sudah banyak berjalan terlebih dahulu tanpa keberadaan peraturan yang lebih spesifik sebagai upaya memprediksi isu-isu hukum terkait permasalahan sertifikasi keandalan.

Sebagaimana disebutkan dalam Pasal 68 Ayat 1 PP PSTE, terdapat 5 kategori dalam pelaksanaan sertifikasi keandalan website, yaitu:

a. Pengamanan terhadap identitas;

b. Pengamanan terhadap pertukaran data;

c. Pengamanan terhadap kerawanan;

d. Pemeringkatan konsumen;

e. Pengamanan kerahasiaan data pribadi.

Namun pada Ayat 2 kembali ditegaskan bahwa dibutuhkan Peraturan Menteri untuk mengatur kategorisasi sertifikasi keandalan tersebut. Idealnya keberadaan Peraturan Menteri tersebut dapat melengkapi unsure dari Prescriptive Approach pada konteks E-Commerce Indonesia, yang apabila pelaksanaannya diselaraskan dengan Minimalist Approach maka gabungan pendekatan keduanya dalam bentuk Hybrid Appproach dapat tercapai.

Sebagai salah satu perbandingan, Uni Eropa menerapkan The Data Protection Directive on The Protection of Individuals With Regard to The Processing of Personal Data and The Free Movement of Such Data 1995 sebagai instrument utama tentang perlindungan data di Uni Eropa yang meliputi aktivitas baik pemerintah maupun bisnis (Shinta Dewi, 2009). General Directive ini memiliki beberapa prinsip yaitu Keabsahan, Kuantitas, Tujuan Akhir, Transparan, Berimbang, Pemberitahuan, Kerahasiaan dan Keamanan, serta Pengawasan (Shinta Dewi, 2009, 33). Kedelapan prinsip tersebut di atas dapat diadopsi oleh Indonesia apabila Peraturan Menteri telah disahkan sebagai instrument untuk mengatur lebih tegas mengenai keamanan informasi di dalam transaksi elektronik.

\section{Kesimpulan}

Prakteknya sertifikasi keandalan sudah dijalankan di Indonesia, walau kebanyakan yang beroperasi adalah Lembaga Sertifikasi Keandalan Asing, artinya sudah ada pengakuan dari stakeholder terkait. Namun kekurangannya adalah pada pengakuan dari Kemenkominfo yang membutuhkan peraturan hukum yang spesifik, amanat PP PSTE untuk melakukan hal itu belum dilaksanakan karena terkait kendala teknis penyusunan Peraturan Menteri terkait Sertifikasi Keandalan, bahkan saat ini sedang disusun rancangan perubahan PP PSTE yang kemungkinan akan mempengaruhi perancangan Peraturan Menteri tersebut ditambah dengan kesadaran konsumen yang rendah ini juga tercermin dari masih banyaknya konsumen yang menggunakan sosial media sebagai pilihan untuk bertransaksi, sementara sosial media tidak memiliki fungsi utama untuk melakukan transaksi elektronik. Sosialisasi kesadaran konsu- 
men pun dibutuhkan dalam hal ini, ditambah dengan sebuah peraturan terkait yang spesifik dan tegas sehingga diperlukan sosialisasi atas hak-hak konsumen yang lebih masif, khususnya terkait jaminan keamanan informasi dalam melakukan transaksi elektronik, sosialisasi ini dapat dilakukan oleh BPKN dalam bentuk rekomendasi kepada Kementerian Perdagangan untuk menerbitkan sebuah Peraturan Menteri terkait hak-hak konsumen di dalam transaksi elektronik.

\section{DAFTAR PUSTAKA}

BPKN. 2017. Wawancara Terstruktur Peneliti dengan Bagian Pengaduan dan Bagian Pengkajian BPKN tanggal 8 September 2017.

Dewi, Shinta. 2009, Cyberlaw Praktik Negara-Negara dalam Mengatur Privasi dalam E-Commerce. Widya Padjajaran. Bandung.

Dewi, Shinta. 2009. Cyberlaw Perlindungan Privasi Atas Informasi Pribadi dalam E-Commerce Menurut Hukum Internasional. Widya Padjajaran. Bandung.

Djaja, H. 2017. Analisis Terhadap Hak Cipta Konten Informasi Elektronik Pada Situs Informasi. Jurnal Cakrawala Hukum, 5(2), 137-145. doi:10.26905/ idjch.v5i2.695

Djaja, Hendra. 2010. Hukum Telematika (Aspek-Aspek Hukum Informasi dan Transaksi Elektronik). Surya Pena Gemilang. Malang.

Emilda Kuspraningrum, 2011, Keabsahan Kontrak Elektronik dalam UU ITE ditinjau dari Pasal 1320 KUHPerdata dan UNCITRAL Model Law on Electronic Commerce, Jurnal Risalah Hukum, Desember 2011.

Kemenkominfo. 2017. Wawancara Terstruktur Peneliti dengan Bagian Hukum dan Kerjasama Dirjen Aplikasi Informatika Kemenkominfo Tanggal 7 September 2017.

Lahaya, Amirah. Borahima, Anwar dan Burhamzah, Oky Deviany. 2014, Aspek Hukum Sertifikat/Logo Trusted Seller Yang Diterbitkan Oleh Komunitas Online Shop Indonesia, Jurnal Analisis. Vol 3 Nomor 2.
Laila, K. 2017. Perlindungan Hukum Terhadap Konsumen Atas Iklan yang Melanggar Tata Cara Periklanan. Jurnal Cakrawala Hukum, 8(1), 64-74. doi:10.26905/idjch.v8i1.1732

Makarim, Edmon. 2003. Kompilasi Hukum Telematika. Raja Grafindo Persada. Jakarta.

Mansur, Dikdik M. Arief dan Gultom, Elisatris. 2005. Cyber Law Aspek Hukum Teknologi Informasi. Refika Aditama. Bandung.

Maskun dan Meilarati, Wiwik. 2017. Aspek Hukum Penipuan Berbasis Internet. Keni Media. Bandung.

Nugroho, Adi Sulistyo. 2016. E-Commerce Teori dan Implementasi. Ekuilibria. Yogyakarta.

Peraturan Pemerintah Republik Indonesia Nomor 82 Tahun 2012 Tentang Penyelenggaraan Sistem dan Transaksi Elektronik.

Purnama, R. Ratna. 2016, Penipuan Online Diprediksi Masih Marak, www.koran-sindo.com (diakses 13 Januari 2016).

Putra, E. 2016. Pengiriman E-Mail Spam Sebagai Kejahatan Cyber Di Indonesia. Jurnal Cakrawala Hukum, 7(2), 169-182. doi:10.26905/ idjch.v7i2.1906

Raditio, Resa. 2014. Aspek Hukum Transaksi Elektronik; Perikatan, Pembuktian dan Penyelesaian Sengketa. Graha Ilmu. Yogyakarta.

Rosadi, Sinta Dewi. 2015. Cyber Law: Aspek Data Privasi Menurut Hukum Internasional, Regional dan Nasional. Refika Aditama. Bandung.

Setiawan, Ahmad Budi. 2014. Studi Standardisasi Sertifikat Elektronik dan Keandalan dalam Penyelenggaraan Sistem Transaksi Elektronik, Buletin Pos dan Telekomunikasi, Vol 2 Nomor 2.

Sitompul, Joshua. 2012. Cyberspace Cybercrimes Cyberlaw Tinjauan Aspek Hukum Pidana. Tatanusa. Jakarta.

Suherman, Ade Maman. 2005. Aspek Hukum dalam Ekonomi Global. Ghalia Indonesia. Bogor.

Suparni, Niniek. 2009. Cyberspace Problematika $\mathcal{E}$ Antisipasi Pengaturannya, Sinar Grafika. Jakarta. 
Efektivitas Pelaksanaan Sertifikasi Keandalan Website Jual Beli Online dalam Menanggulangi Penipuan Konsumen Eka Nugraha Putra, Wika Yudha Shanty, dan Hatarto Pakpahan

Undang-Undang Republik Indonesia Nomor 11 Tahun 2008 Tentang Informasi dan Transaksi Elektronik.

Undang-Undang Republik Indonesia Nomor 19 Tahun 2016 Tentang Perubahan Undang-Undang Republik Indonesia Nomor 11 Tahun 2008 Tentang Informasi dan Transaksi Elektronik.

Widodo. 2013, Aspek Hukum Pidana Kejahatan Mayantara. Aswaja Pressindo. Yogyakarta.
Widodo. 2013. Memerangi Cybercrime: Karakteristik, Motivasi, dan Strategi Penanganannya dalam Perspektif Kriminologi. Aswaja Pressindo. Yogyakarta.

\section{How to cite :}

Eka Nugraha Putra, W. Y. S. dan H. P. (2017). Efektivitas Pelaksanaan Sertifikasi Keandalan Website Jual Beli Online Dalam Menanggulangi Penipuan Konsumen. Jurnal Cakrawala Hukum, 8(2). 